\title{
Exploring Diplomatic Crisis of Nigeria and South Africa between 1994 and 2013
}

\author{
Samuel Augustine Umezurike \\ Department of Politics and International Studies (POLIS), University of Zululand, KwaDlangezwa, South Africa \\ agonwachuku@yahoo.com or UmezurikeS@unizulu.ac.za \\ Dr Asuelime E Lucky
}

Department of Politics and International Studies (POLIS), University of Zululand, KwaDlangezwa, 3886, South Africa

Email: lucky4real14@gmail.com

\section{Doi:10.5901/ajis.2015.v4n1p65}

\section{Abstract}

Nigeria's relations with South Africa were of double standard during the apartheid era. The post-independence Nigeria and the apartheid regime in Pretoria relations were sour and confrontational, while it was friendly between Nigeria and the liberation movements in South Africa, especially with the African National Congress (ANC). It was more so because Nigeria adopted Africa as the centerpiece of its foreign policy, and committed itself to the total liberation of the African continent from colonialism and racism. Nigeria staged untiring opposition to colonialism on the African continent, and the racism that existed in South Africa before 1994. The beginning of a new era started in the final days of apartheid in South Africa when President de Klerk visited Nigeria in April 1992 to discuss bilateral issues, mostly trade relations. The paper examines, however, Nigeria and South Africa's diplomatic fluidity since re-establishing formal relations in 1994 in order to understand the causes of the misunderstanding and the effect on both countries' relations and suggest better ways to foster their relations. The study argues that Nigeria plays big brother roles in Africa from 1960 but is now unable to continue with such big brother projects. South Africa on the other hand quickly recognized economic opportunities in Africa and seek to establish neo-imperial post in the continent. However, the study suggests that the two African giants can have a smooth relations but Nigeria needs to step up its development in order to create parity with South Africa to help them form alliance of strength for Africa. It also notes that South Africa is the real giant of Africa, but Nigeria covers her internal weaknesses while engaging in diplomacy, especially with South Africa.

Keywords: Diplomatic relations, bilateral relations, General Sani Abacha, Nelson Mandela, democratizing, African renaissance, foreign policy in Africa, big brother Nigeria and neo-imperialist south Africa, African giants, yellow fever.

\section{Introduction}

This essay aims at exploring and explaining the two major diplomatic failures between the two most powerful nations in Africa, Nigeria and South Africa, since 1994 with the possibility of understanding causes and the effects on the diplomatic relations of the two giant nations of Africa. The two countries have the two largest economies in Africa, South Africa taking the lead because of her more capitalized economy with advantage in infrastructure, science and technology, while Nigeria is the second largest economy in Africa owing to her population and the blessings this most populous black nation in the world enjoys in oil as well as human resources (see Marwa, 2010). The state of Nigeria has suffered many years of squandering at the hands of her erstwhile military leaders and politicians (Idowu, 2008). This has been a major setback in the body politics of Nigeria.

This essay uses content-analysis based on literature, electronic, and print media to explore the diplomatic breakdowns of the two most influential countries in sub-Saharan Africa. Adopting a qualitative method of research, the essay describes and analyses the two major diplomatic crises between Nigeria and South Africa. The study uses Nigeria's withdrawal from the 1996 African Cup of Nations hosted by South Africa, and the most recent deportations of travelers between the two countries owing to the yellow fever vaccination card scandal to argue that the failure of the two countries to form a workable alliance is a setback to their relations and as such have not enhanced productivity in their relations.

One of the reasons for using content-analysis based on secondary data is because the necessary data for the examining the diplomatic crises of Nigeria and South Africa is already available in literature, electronic, and print media. 
Another reason is that it would be impossible to interview the individuals involved in those crises and even if they would be met for interviews their views might not be relied upon since they might be biased in their versions of the story. These make content-analysis based on secondary data the most suitable methodology for this study.

\section{Background to Nigeria-South Africa's Bilateral Relations Since 1994}

The expectations around the world that Nigeria would play a pivotal role in the reviving of Africa after its independent on 1 October 1960 had diminished to a great extent at the time South Africa re-entered the comity of nations as a democracy in the 1994. The only memorable thing left was remembrance of Nigeria's role in the liberation of Africa from colonialism, and the special support she gave to the abolition of apartheid in South Africa (see Aremu, 2013). The diminishing influence of Nigeria could be blamed on her economy, which failed largely because of the successive military regimes in the country.

However, the new democratic regime in Pretoria, the popular government of national unity (GNU) led by the antiapartheid icon, President Nelson Mandela, quickly established bilateral relations with Nigeria in 1994, though the latter was under the military leadership led by late General Sani Abacha. The move was in recognition of Nigeria's role in the liberation of apartheid South Africa. Though the formal relationship was established between Nigeria and South Africa, Banjo (2010) remarked that the Mandela-Abacha relationship did not measure up to African expectations because it was characterized by mistrust and conflict between the two administrations (also see Aremu, 2013). One of the major issues was the demand by President Mandela that Nigeria should democratize in line with the Harare Declaration in 1991 by the Commonwealth Heads of State and Government (see Ndlovu, 2010).

Pretoria's assumption of moral authority to advise on democracy and the advancement of human rights was based on what South Africa had adopted as her pillars of foreign policy after 1994, but was misinterpreted by Nigeria's military junta as an attempt by Pretoria to set up competition between the two countries which Nigeria claimed she was not interested in (Banjo, 2010). Nigeria's side of the argument was in itself a distortion of the facts. For example, military involvement in politics was already out of fashion in the world. The relationship between the two countries was tense because of Abacha's desire to hang onto power, and gross abuse of human rights in Nigeria (Banjo, 2010).

Nigeria had witnessed successive military juntas led by Major-General Mohammadu Buhari which cut short about five year old democracy led by President Shehu Shagari. On 27 August 1985 there was another military takeover in Nigeria, popularly known as a 'palace coup', headed by General Ibrahim Babangida. Babangida, the so-called 'Maradona' of Nigerian politics, who deceived Nigerians with his unfulfilled promises of handover to a democratically elected government in early1990s. The transitions were successively postponed, but the end was the unpopular annulment of the June 12, 1993 presidential election judged by expert analysts as the most credible election ever to have been held in Nigeria (Banjo, 2010).

Largely because of international and national pressure on the military junta, General Babangida stepped aside and installed a weak administration popularly known as the Interim National Government headed by Chief Ernest Shonekan, who was sworn in as Nigeria's ninth head of state. The move was to the amazement of Nigeria and the world as the choice was not the self-proclaimed winner of the June 12 presidential election, Chief M. K. Abiola. The ING was generally viewed as lacking a popular mandate, it were not surprise that the ING had lasted for barely three months when on 17 November 1993 the then Head of State claimed to have resigned. In fact it was yet another coup d'état in Nigeria (Banjo, 2010). The only thing that looked different from the previous coups was the mild nature of the military takeover; but that could be attributed to the weakness of the ING. The government was largely regarded as illegitimate in view of the circumstances that had brought it to power.

The leader of the new military regime in Nigeria was General Sani Abacha, who announced the suspension of all democratic structures and activities as usual with military leadership but to public dismay, constitutional provisions were quickly replaced by arbitrary decrees, which paved the way for the junta to embark on gross human rights abuses in disregard of the judiciary. The regime soon faced unprecedented opposition from human rights groups and crusaders for democracy because Abacha was seen by many as an insider of the Babangida's military junta, who could only extend Babangida's agenda in the Aso-rock (Abuja), Nigeria's sit of power. Ababach's response in the face of opposition was use of brutal force through the State security apparatus. Banjo (2010) summed it up when he wrote that the military government was characterized by extrajudicial killings, assassinations, and torture by the state security, the abrogation of civil liberties, and the curtailment of political and labour affiliation. Nigeria at this stage entered into one of the worst stages of human rights abuse of its history.

General Sani Abacha's resolve to remain in power instead of democratizing further aggravated the poor human 
rights situation in the country as he went on to arrest and detain, Chief M. K. Abiola who was widely known as the winner of the June 12, 1993 presidential election. President Nelson Mandela, who had ascended to a position of international personality, visited Nigeria in 1995 to plead for the release of Abiola (Banjo, 2010). Banjo identified three major sources of pressure on President Mandela: President Clinton's administration in the US, African leaders, and Abiola's family and supporters. The Nigerian government downplayed the Mandela visit as merely a solidarity visit which South African diplomatic sources disputed and blamed Abacha as the man who was plunging Nigeria into political crises assessed to be similar to what had happened in Rwanda (Banjo, 2010) .

At this stage Mandela's growing international prestige brought more pressure on him from Western and African leaders in both non-governmental and governmental institutions to step up initiatives that would resolve the Nigerian crisis and secure the release of Abiola. Mandela took a further step by sending the renowned South African Nobel Peace Prize laureate, Archbishop Desmond Tutu, to Abuja in April 1995. The move still did not yield any result as Abacha did not promise anything, and Tutu reported back to Mandela that his attempt was fruitless. However, he advised that Mandela should consult further with Abacha (Banjo, 2010).

In another poor move of the military junta, a group of purported coup plotters who were suspected of plotting to overthrow the Abacha regime were arrested, the most prominent of whom were General Olusegun Obasanjo (former Nigerian head of state), and Major-General Shehu Musa Yar' Adua. Mandela yet again made significant effort to intervene by sending his deputy president, Thabo Mbeki to Nigeria in July 1995. The move was a calculated attempt by Mandela to capitalize on the diplomatic experience of his able deputy who had negotiated so much for the ANC during the apartheid struggle. He had also been the ANC's representative in Nigeria between 1976 and 1978 at a time Obasanjo was Nigeria's military head of state. Mbeki's three-day working visit did not bear fruit because Abacha made no promise to release Abiola and other important political detainees (Banjo, 2010).

During the Commonwealth summit in Auckland, Mandela's conviction that he had received General Sani Abacha's firm promise of clemency for the 'Ogoni nine' (Ken Sarowiwa and eight others) was to no effect when he learnt of their sudden execution. Mandela felt betrayed because of his assurance to fellow Commonwealth leaders that the executions would not take effect. He believed he had used his moral stature to discourage Abacha from carrying out the hangings, and angrily accused Abacha of behaving like a frightened dictator who engaged in extra-judicial killings (Banjo, 2010). He concurred with the British premier, John Major that Abacha was sitting on a volcano and he promised to explode it under him. He called on the West to impose oil sanctions on Abacha's regime, and advocated Nigeria's expulsion from the Commonwealth (Adebajo, 2007). This simply meant a switch of position between Nigeria and South Africa. In the apartheid days, Nigeria had successfully championed the expulsion of South Africa from the Commonwealth, which was successful and held until the end of apartheid (Arema, 2013).

On his return home, Mandela recalled his High Commissioner to Nigeria, George Nene, who had been somewhat heavily criticized by South African civil society groups for failing to make contact with Nigerian opposition groups, and being close to unscrupulous leaders in Abuja. Nigerian leaders felt otherwise - that Nene had become too close to the opposition, and had lost all understanding with the Abacha led government in Abuja (Adebajo, 2007)

\subsection{Nigeria Withdraws from 1996 African Cup of Nations}

In December 1995, Mandela called on SADC summit to take collective action against Nigeria on the grounds of human rights abuse and indiscriminate extrajudicial killing. According to Banjo and Omidiran, (2000), Abacha responded by refusing to let the Nigerian Super Eagles defend their African Cup of Nations gold medal (which the Nigerian team had won in 1994 in Tunis) in South Africa in 1996. In Nigeria's calculation, the first indication that South Africa intended to use sports as a weapon was when South Africa withdrew the invitation of Nigeria's Super Eagles to the four-nation tournament organized by South Africa. The South African Football Association alleged that it was because of the hanging of the 'Ogoni 9' that the invitation was withdrawn. The Nigerian sports authorities protested to FIFA asking for South Africa to be punished for mixing sport with politics. Nigeria based her argument on the ground that suspension of Nigeria from the Commonwealth because of the killing of the 'Ogoni 9' was a political issue which should not have influenced sports decisions. FIFA agreed but only warned South Africa, promising, however, to punish her if there were any future occurrence of mixture of sport and politics (Banjo and Omidiran, 2000).

Nigeria, a master specialist in using sport to advance political interest, recalled that CAF 1996 in South Africa provided an ample opportunity for her to outsmart South Africa in this time of diplomatic breakdown between the two countries. This would be similar to the positions that Nigeria had taken on sport to score political points against the apartheid regime. Chief Tom Ikimi, Nigeria's Foreign Affairs Minister who was also the former Chairman of the defunct 
National Republican Convention (NRC), one of the political parties that contested elections in Nigeria's failed third republic, wanted success in defending the worst Nigerian notorious regime around the world (Banjo and Omidiran, 2000). He was said to have presented a shabby and highly contested report of the hostile attitude South Africa promised Nigeria's team, sports officials and supporters if they dared come to South Africa in 1996. The main thrust of the report which was obtained from Nigeria's High Commission in South Africa was that there would be no Nigerian representatives in the competition (Banjo and Omidiran, 2000). The South African decision to deny Nigeria's then Minister of Sport, Chief Jim Nwaobodo a visa constituted evidence, though under CAF and FIFA rules South Africa was not obliged to issue visas to officials of a sports ministry but only to players, fans, and officials of Football Associations (Banjo and Omidiran, 2000). However, refusal of visa application to such a high profile Nigerian was not acceptable to the leadership

The situation was further aggravated by Nigeria's Minister of Information, Walter Ofonagoro's, accusation of Nelson Mandela of being a black head of a white country' who could not be trusted. Adebajo (2007) observed that it was a particularly hurtful and insensitive statement that hit at the most sensitive spot of a black-led government that had inherited a country in which whites still controlled the economy and economic institutions. Continuing, he explained that ordinary South Africans would not easily forgive Nigeria for this personal slur on the country's saintly hero. Mandela's inexperience in the complexities of African diplomacy was shown in his inability, despite his iconic status, to acquire a single Southern African state to take action against Nigeria.

In the end, Nigeria boycotted the 1996 CAF competition in South Africa (Banjo, 2010). This was clearly a situation that could have been managed better if not for the misuse of words on the part of South Africa who was so much dependent upon the personality and moral status of its President. Nigeria on its part was pretending that all was well with its internal politics and the military leaders in Nigeria miscalculated by expressing that Nigeria's relations with South Africa should only be defined by its contribution to the peaceful end of apartheid. Both countries undermined real issues in foreign policy.

\subsection{The Revival of Relations Between Nigeria and South Africa}

In June 1998 General Sani Abacha's untimely death seemed to have turned events around between the two countries. The South African Deputy President, Thabo Mbeki, travelled to Nigeria to urge the newly appointed head of state, General Abdulsalami Abubakar, to release political prisoners, protect human rights, and ensure press freedom and turn on the green light for safe return of exiles (Banjo, 2010). In August the same year, General Abdulsalami Abubakar returned the visit. Abubakar also extended an invitation to President Nelson Mandela to the ECOWAS summit to be hosted in Abuja, Nigeria. These moves paved the way for the revival of cooperation between the two countries (Banjo, 2010). The gentle Abubakar handed over to a democratically elected government on 29 May 1999, imitating President de Klerk who had earlier in 1994 piloted the transition from apartheid to democracy in South Africa. Interestingly, General Olusegun Obasanjo, who succeeded General Abubakar, would on his first foreign trip as democratically elected President of Nigeria attend the inauguration of his friend, Thabo Mbeki, as President of South Africa in June of the same year.

Not long after, improvement of relations between the two countries was to depend largely on the Binational Commission which was a strategic coordination of economic bilateralism between the two countries. The commission was formally established in October 1999, to be co-chaired by the Vice-President and Deputy President of Nigeria and South Africa respectively (Banjo, 2010). According to Adebajo, (2007), the Binational Commission has major objectives which he highlighted as being to provide a framework for joint efforts to bring Africa into the mainstream of global political, social, and economic developments; provide the basis for the government and private sectors of both countries to consult with each other to promote bilateral trade and industry; improve bilateral relations in the fields of technology, education, health, culture, youth, and sports; use both countries' human and natural resources to maximize socio-economic development through collaborative efforts; and establish the mechanisms to promote peace, stability, and socio-economic integration in Africa. According to Adebajo, (2007), Nigeria and South Africa held six BNC meetings, alternating them between the two countries. Those meetings were held in October 1999, April 2000, March 2001, March 2002, December 2003 and September 2004.

According to Adebajo, (2007), the BNC intended to address some issues that have negatively affected the relationship between Tshwane and Abuja including Nigerian diplomats complaining about negative South African press reports and xenophobic stereotypes depicting Nigerians as drug traffickers and criminals. Nigerian diplomats contend that local South Africans, Chinese, Asians, Europeans and Arabs are also engaged in the illegal business of drug dealing, but they are not tarred with it. A Johannesburg radio station, 94.7 Highveld, was forced by South Africa's Broadcasting Complaints Commission to apologize after it claimed that the Nigerian President, Olusegun Obasanjo, was carrying 
cocaine in his bag when he came to attend Mbeki's inauguration in June 2004 (Adebajo, 2007). In spite of the framework of BNC and numerous bilateral agreements Nigeria has signed with South Africa, the two countries have not been able to maintain absolute cordial diplomatic relation. There have also been minor sporadic diplomatic breakdowns between the two countries, but another worrisome crisis broke out in 2012 popularly known as yellow fever card deportation.

\subsection{Yellow Fever Card Deportation}

Another major diplomatic row erupted between Nigeria and South Africa, with the former alleging that President Jacob Zuma's led government was 'taking decisions that were disrespectful to Africa. This was as a result of the deportation of 125 Nigerians who landed at OR Tambo International Airport. On 5 March, 2012 the group was prevented from entering South Africa because they did not have the required documentation for vaccination against yellow fever as required by South African port health authorities. Reports showed that 75 of them were sent back home via South African Airways, and another 50 were flown back by the Nigerian airline, Arik Air (Moeng, 2012).

The Soweto reported that Nigeria's Foreign Affairs Minister, Gbenga Ashiru, vowed to reciprocate the gesture by demonstrating that South Africa does not have a monopoly in deporting travelers. In a surprise move, described by many as retaliatory, 28 South Africans were turned back at Murtala Muhammed International Airport in Lagos, and another 56 were deported between $6^{\text {th }}$ and $7^{\text {th }}$ of March 2012. After six days of diplomatic stand-off, a total of 256 nationals of both powerhouses, Nigeria and South Africa, were carelessly deported to their respective countries without due process. Nigeria this time took a pound of South Africa's flesh by deporting a total of 131 South Africans (Moeng, 2012). According to The Sowetan, the South African International Relations and Cooperation Department's spokesman, Clayson Monyela, claimed that Nigeria was blowing things out of proportion and mixing issues. The Department further stated that it was a health matter, claiming that it was only being elevated to a diplomatic issue by Nigeria (Moeng, 2012).

According to The Sowetan, the South African Department of Home Affair's spokesperson, Ronnie Mamoepa, also claimed that the Department followed standard international protocol in the deportation. He advised the public to understand that communicable diseases must be controlled. The spokesperson of the Department of health, Fidel Hadebe, was of the opinion that South Africa was in line with the country's policies, which are also in line with WHO (World Health Organization) guidelines on disease control.

However, a gentleman's agreement was reached after the South African government formally sent a letter of apology to Nigeria's Minister of Foreign Affairs, Olugbenga Ashiru, apologizing for barring 125 Nigerians from entry into South Africa over alleged possession of fake yellow fever vaccine cards. Nigeria in turn accepted the apology of the supposedly guilty opponent, South Africa. According to The Sowetan, both countries decided to put in place certain mechanisms to ensure that a similar development does not reoccur. The intention was to protect the bilateral relations and agreements between the two countries. The five measures Nigeria and South Africa agreed upon included:

- The revival of the Binational Commission between South Africa and Nigeria and the Immigration Working Group as soon as possible.

- South Africa's national Department of Health and the Gauteng Health Department to reconsider reopening the vaccination clinic at the OR Tambo International Airport so that passengers without the yellow fever card can be vaccinated upon arrival at the airport to avoid undue deportation.

- The South African and Nigerian health authorities would exchange vaccine batch numbers and details about the official institutions that administer the vaccine for verification purposes at the port of entry. This information would also be made available to the missions in Lagos and Abuja who issue visas based on the proof of a yellow fever certificate. The airlines will also be informed about the verification process.

- Immigration officials would be the first officials that deal with the travelers at the port of entry, and if they should experience challenges, they should invite other units such as Health to help, and not the other way round.

- In the case of mass deportations, senior officials at the Department of International Relations and Cooperation, including Protocol, should be consulted by Immigration and Health officials at the airport before undertaking such action. This will provide opportunity to senior officials to consult with the Department before deportation of large numbers of people.

\section{The African Giants}

According to Ajaebili (2011), the core principles of Nigeria's foreign policy as generally agreed upon by scholars include: 
a. The Principle of Non-Alignment: This is a rejection of alliance with the existing ideological and military power blocs of the capitalist West led by the United States and the communist East led by the former Soviet Union during the cold war era. It was particularly important because Nigeria gained independence during the heat of cold war.

b. Legal Equality of States: Nigeria adopted the principle of respect for the legal equality, sovereignty and territorial integrity of all states, big or small. This was designed to protect the small and newly independent states from the domineering influence of the developed nations.

c. Non Interference in the Domestic Affairs of other state: Nigeria upheld the principle of non-interference in the internal affairs of other countries.

d. The Principle of Multilateralism: This implies the freedom to seek membership of both continental and global multilateral organizations.

e. Africa as the Centre piece of Nigeria's Foreign Policy: Africa has remained the cornerstone of Nigeria's foreign policy since independence

It is generally accepted that a vibrant foreign policy derives its strength from domestic imperatives, that is, from the needs of the country and the populace. Africa has remained the centre piece of Nigeria's foreign policy since independence in 1960 (Ajaebili, 2011). The country has therefore spent heavily in pursuit of the decolonization of Africa and terminating the apartheid regime in Pretoria, aggressively championing the freedom of Africans in various countries such as Congo, Angola and Mozambique when they were under the yoke of colonialism, and of others under the minority racist regimes in Zimbabwe and South Africa (Ajaebili, 2011).

Nigeria has played an unmatchable role in restoring peace to conflict-ridden African countries such as Congo, Sudan, Liberia and Sierra Leone (Ajaebili, 2011), to which she always committed huge human and material resources. Nigeria has, however, continued to endure the mockery of several African states notwithstanding her big brother role in Africa. For instance, some neighbouring Francophone countries embarrass Nigeria and show outright hostility by subjecting Nigerians living in their midst to various forms of torture and other humiliation (Ajaebili, 2011). Nigerians in Southern African countries, and particularly in South Africa, face a similar fate generally termed as xenophobia (see Umezurike and Isike, 2012). This poor perception of Nigerians in the international community could be blamed on the unscrupulous political leadership and economic breakdown which the country has experienced for several years owing to the opportunities squandered by the successive military regimes in the country.

In 1993, South Africa's apartheid hero and ANC leader, Nelson Mandela, published a detailed exposition of the philosophical pillars that support South Africa's foreign policy. According to him they include:

a. that issues of human rights are central to South Africa's international relations and extend beyond the political to economic, social and environmental issues;

b. that just and lasting solutions to the problems of humankind can only be achieved through the promotion of democracy in the world;

c. that considerations of justice and respect for international law should guide the relations between South Africa and other nations in the world;

d. that peace is the goal for which South Africa and all nations should strive, and where this fails, internationally agreed but non-violent methods, including effective arms control regimes, must be employed;

e. that the concerns and interests of the continent of Africa should be reflected in South Africa's foreign policy.

f. that the economic development of South Africa depends on growing regional and international economic cooperation in an interdependent world.

However, the concept of African Renaissance comprises a philosophy which calls on African people and nations to overcome the current challenges confronting the continent. The concept was popularized by former South African President Thabo Mbeki during his term of office as Deputy President and subsequently President. As such, it has been an essential ingredient of the post-apartheid South African intellectual agenda which has continued to shape South Africa's foreign policy towards Africa. In April 1997 Mbeki articulated the elements that comprise the African Renaissance to include, among other things, social cohesion, democracy, economic rebuilding and growth, and the establishment of Africa as a significant player in the geopolitical affairs of the world. Among other numerous objectives, the African Renaissance is a philosophical and political movement which intends to eradicate the violence, elitism, corruption, poverty and general underdevelopment that has engulfed the African continent, and ultimately replace them with a more just and equitable order. Mbeki proposes doing this by, among other things, encouraging education and the reversal of the brain drain of African intellectuals. He also urges Africans (led by African intellectuals) to take pride in their heritage, and to take charge of their lives. Some scholars have argued that the African Renaissance is equivalent to the Pan- 
Africanism project which seeks to unite Africa (see Zeleza, 2009).

However, the big question here is: how does South Africa fare in terms of moving from theory to practice of implementing the spirit and vision of the African Renaissance in terms of her foreign policy in Africa? Since the advent of democracy in South Africa in 1994, which marked the end of South Africa's isolation from the rest of the world, she has established her presence and influence in a number of ways, especially in Africa. The notable spheres in which South Africa has played major roles in Africa include sport, economics and political leadership. In sport, South Africa emerged from isolation in 1994 to host the first ever FIFA-organized World Cup on African soil (see Ndlovu, 2010). In economics South Africa has demonstrated that it has the most sophisticated capitalist economy in Africa in terms of trade, debt and foreign investments in Africa and beyond (Mahao, 2006; Tjemolane, 2011; Alden and Soko, 2005; Nicole, 2004). In terms of political leadership, South Africa has emerged as a regional and continental power in peacekeeping and negotiation in conflict areas such as the DRC, Burundi, Angola, Lesotho, Sudan and Zimbabwe (see Spence, 2004; Habib \& Selinyane, 2004; Wannenburg, 2004; Ngubentombi, 2004). But to what extent do all this promote cooperation between Nigeria and South Africa?

\subsection{Big Brother Nigeria and Neo-Imperialist South Africa}

According to Campbell (2006), Nigeria staged the second World Black and African Festival of Arts and Culture (FESTAC) in 1977. Campbell used the festival to examine the many problems standing in the way of Nigeria's move toward new leadership in the present century. According to him, FESTAC, in fact, revealed a society drifting in the wrong direction. The organizers claimed that the festival was an arena for bringing together peoples of African descent to exhibit and celebrate their shared heritage. Another claim was that it was aimed at exploiting Nigeria's newly attained economic strength and muscle for political advantage on the global scene. But all hopes were soon dashed away because of ethnic and regional division and corruption in the country. According to Campbell, FESTAC was an avenue for looting money. It amounted to big waste in a society in urgent need of economic reform and political revival. It was also a story of grand betrayal and exploitation of the weak, the vulnerable, and the defenceless, orchestrated in large measure in collusion with Western industrial capital Campbell (2006). Such big brother roles as Nigeria had embarked upon, which signified lack of direction in her economic and political leadership, had seen the international respectability of Nigeria diminish remarkably in recent years.

Nigeria was a frontline state in support of liberation movements in Southern Africa because of her commitment to what she considered a just struggle for freedom in the region. For this end Nigeria established the big brother project of the Southern African Relief Fund (SARF) (see Aremu, 2013). This was specially funded with deductions from the salary of every Nigerian worker, irrespective of rank, both in the public and private sectors as well as donations from ordinary Nigerians in all walks of life, including students (see Aremu, 2013). This fund was made available to the liberation movements in Southern Africa. Nigeria further provided scholarships for students from South Africa. Nigerian artists also contributed in this struggle. For instance, Nigerian musicians waxed albums in support of the anti-apartheid struggle. A memorable one in this respect was Sonny Okosun's timeless piece, 'Fire in Soweto'. At the international level, Nigeria provided leadership at the United Nations and the Organization of African Unity (now the African Union). For example, Nigeria chaired the UN Special Committee against Apartheid (UNSCAA) for most of its existence (see Aremu, 2013). Nigeria also championed the isolation of apartheid South Africa until that country's freedom in the 1990s. In sport, Nigeria engineered boycotts and the isolation of South Africa because of apartheid (see Banjo and Omidiran, 2000)

South Africa at freedom in 1994 on the other hand, engaged in an African Renaissance that saw her expand her neo-imperial interests in Africa. For example, South Africa's economic dominance in Africa is demonstrated through her production of approximately $80 \%$ of Southern Africa's GDP. A lopsided trade relationship exists between South Africa and her neighbours, with South Africa having a surplus advantage over fellow SADC members. South Africa's estimated economic output is US $\$ 160$ billion, far more than that of the other 13 SADC member states, which jointly produce only about US $\$ 33$ billion (Alden and Soko, 2005). South Africa has also emerged as the largest foreign investor in Southern Africa. South Africa's direct investment in the 13 SADC countries has been estimated to be over US\$5.4 billion by 2000. According to Alden and Soko, (2005) in 2001, South Africa's investment in Southern Africa is estimated to have amounted to R14.8 billion (US\$20 million) by South African Airways (SAA) for its stake in Air Tanzania; US\$6 billion by Eskom Enterprises in the Inga project in the Democratic Republic of Congo (DRC); US\$56 million by Sun International in its hotel in Zambia; US\$142 million by Vodacom in Tanzania, and an additional US\$139 million investment in the DRC; US\$53 million by Pretoria Portland Zimbabwe in merger activity in Zimbabwe; a US\$860 million investment by BHP Billiton, the IDC and Mitsubishi in the development of the Mozal aluminium smelter in Mozambique; and a further 
investment of US $\$ 1.1$ billion by Sasol in the Pande and Temane gas fields in Mozambique (Alden and Soko, 2005).

South Africa's total trade with the rest of the continent is heavily skewed in her favour. South Africa's exports to Africa, mostly manufactured goods, increased from U\$1.3 billion in 1994 to US\$5.9 billion in 2003, while imports from Africa to South Africa increased from a low base of US\$0.4 billion to US\$1.2 billion during the same period (Alden and Soko, 2005).

South Africa's economic dominance in Africa has seen growth in trade and investment between the two biggest economies in the continent, South Africa and Nigeria, with South Africa taking the lead. Both countries are also Africa's major regional powers in economics and politics. Nigeria has become South Africa's biggest trade partner in West Africa and her third largest on the African continent after Zimbabwe and Mozambique. This compares poorly with a relatively weak balance of trade for Nigeria with South Africa. South Africa's economic foray into Nigeria has been encouraged at the highest political level, even though most firms have entered the country under their own umbrella through the NigeriaSouth Africa Chamber of Commerce. Aremu (2013) reported that South Africa paraded an estimated gross domestic product (GDP) of $\$ 368$ billion in 2011 as Africa's biggest economy, while Nigeria, Africa's second biggest economy by GDP, recorded some $\$ 232$ billion. Nigeria has regrettably been pushed back to de-industrialization with just less than 4 per cent manufacturing value added to GDP, while South Africa, as the leading industrializing nation in Africa, parades the highest manufacturing value added number of 24 per cent

In the past decade, over 100 South African companies, with the support of the Department of Trade and Industry, have penetrated the Nigerian market in different economic sectors. Several South African companies now operate in Nigeria. These include: MTN, Eskom Nigeria, South African Airways, Stanbic Merchant Bank Nigeria Ltd., Multichoice Nigeria/M-Net,Umgeni Water, Defresh Products Nigeria Ltd., South Africa-Nigeria Communications and Systems Ltd., Grinaker-LTA Construction Ltd. ,Protea Hotels, Critical Rescue International, Global Outdoor Semces, Oracle Airtime Sales, and Digital Satellite Television. Only a handful of Nigerian companies have set up business in South Africa. These include Union Bank, First Bank, Philips Consulting, News Media, Financial Standard and This Day Newspapers (Adebajo, 2007; Zeleza, 2009; Aremu, 2013).

\section{Conclusion}

Nigeria at independence pursued a clear policy of decolonization, and eradication of racism in Africa. She also pursued big brother projects like the sponsorship of liberation movements in Africa and the FASTAC 1977. But evidence shows that largely because of lack of economic and political leadership, the foreign policy of almighty Nigeria became stranded and confused at the time South Africa was freed from apartheid. Nigeria is willing to partner with South Africa on political and economic bases. But Nigeria's leadership is not willing to standby and be embarrassed because of its internal weakness. The weakness is mostly the result of political instability, lack of sound economic direction, and endemic political and economic corruption in the country.

South Africa, on the other hand, at democratization in 1994 felt disappointed that Nigeria, that should have been providing leadership and leading by example in Africa, was still under military rule and experiencing gross human right abuse, all of which South Africa later converted to her advantage. South Africa pursues a foreign policy of a better South Africa, a better Africa and a better world. However, her leaders popularized the African Renaissance which she is using as an umbrella to expand her business treks in the continent. South Africa has the capacity that is required to lead Africa from poverty to prosperity which Nigeria lacks. However, she is able but unwilling to provide the economic leadership similar to the political leadership Nigeria provided during decolonization in Africa and apartheid in South Africa. For example, South Africa has allowed xenophobia to damage her human rights standing and international respectability. Unfortunately this highly damaging hostility is directed against African foreigners residing in South Africa.

The diplomatic feuds between Nigeria and South Africa occur largely because of the differences in their attitudes in terms of African need. It could be said that Nigeria is willing to lead Africa in any direction, but cannot do so right now, especially in economics; while South Africa is able but certainly unwilling to make any sort of sacrifice to Africa. Africa is doomed in the $21^{\text {st }}$ century if the continent has to rely on the axis of Nigeria and South Africa. The hegemony of Nigeria and South Africa is not workable at this stage. For both countries to form hegemony for African prosperity, Nigeria needs to be more competitive in the world economy in order to create parity between her and South Africa for peaceful purposes that support the cause of it relations with South Africa. Such parity will accelerate Nigeria's development and like manner open up space for respect from South Africa in its relations with Nigeria. 


\section{References}

Adebajo, A. (2007), South Africa and Nigeria: An Axis of Virtue? A paper presented for the Harold Wolpe Memorial Trust Open Dialogue, Lecture Theatre 3A, Leslie Social Science Building, South Africa, Unpublished.

Ajaebili, C. N. (2011). The option of economic diplomacy in Nigeria's foreign policy. International Journal of Humanities and Social Science, 1(17), 277-280.

Alden, C. \& Soko, M. (2005). Africa's economic relations with Africa: Hegemony and its discontents. Journal of Modern African Studies, 43(3), 367-392.

Aremu, I. Africa: Wither Whither South Africa-Nigeria Bi-national Commission? Daily Trust. http://allafrica.com/stories/201305200417. htmlAccessed July 18, 2013.

Banjo, A. (2010). South Africa-Nigeria diplomatic and economic relations, 1994 to 2004. African Review, Journal of African Studies Association of India, 2(1), 81-93.

Banjo, W. S. \& Omidiran, P. O. (2000). Politics in international sports: The Nigerian experience. Lagos: Afreb.

Campbell, B. (2006). The Pan-African nation: Oil and the spectacle of culture in Nigeria. African Studies Review, 49(1), $132-133$.

Habib, A. \& Selinyane, N. (2004). South Africa's foreign policy and realistic vision of an African century. In Sidiropoulos, E, (Ed), Apartheid past, Renaissance future (pp.49-60). Johannesburg: The South African Institute of International Affairs.

Idowu, A, A, (2008), 'Human Rights, Democracy and Development: The Nigerian Experience' Research Journal of Internatıonal Studıes - Issue 8, pp.27-41.

Mahao, L. (2006). The power of hegemonic theory in Southern Africa: Why Lesotho cannot develop an independent foreign policy. Unpublished Master's dissertation, Rhodes University, Grahamstown.

Mandela, N. (1993). South Africa`s future foreign policy: Foreign Affairs, 72(5) http://www.anc.org.za/show.php?id=4113, Accessed July $10,2013$.

Marwa, M, B, (2010), a Paper Presented by the High Commissioner of Nigeria to South Africa at the Occasion of Nigeria's 50th Independent Day Anniversary at the Human Science Research Council Pretoria, http://www.hsrc.ac.za/uploads/pageContent/225 /paperSeminarNigeria50.pdf.

Moeng, K. (2012, March 8). Stand-off after SA deports 125 Nigerians. Sowetan, p.? http://www.sowetanlive.co.za/news/2012/03/08/ stand-off-after-sa-deports-125 nigerians Accessed July 20, 2013.

Ndlovu, S. M. (2010). Sports as cultural diplomacy: The 2010 FIFA World Cup in South Africa's foreign policy. Soccer and Society, 11(12), $144-153$

Ngubentombi, N. (2004). Overview of bilateral and regional relations. In Sidiropoulos, E, (Ed), South Africa's foreign policy 1994-2004: Apartheid past, Renaissance future (pp. 185-204). Johannesburg: The South African Institute of International Affairs.

Nicole, H. (2004). South Africa in the African political economy: Benevolent or selfish hegemon?

Spence, J. (2004). South Africa's foreign policy: Vision and reality. In Sidiropoulos, E (Eds), South Africa's foreign policy 1994-2004: Apartheid past, Renaissance future (pp. 61-84). Johannesburg: The South African Institute of International Affairs.

Tjemolane, T. (2011). South Africa's foreign policy towards Africa, 1994-2010: Partner or hegemon? Unpublished Master's dissertation, University of the Free State, Bloemfontein.

Umezurike and Isike, (2013), An analysis of Opinions of African Immigrants on Service Delivery by the Department of Home Affairs, South Africa, Inkanyiso, Vol. 5, No 103: 52-62.

Wannenburg, G. (2004). From pariah to pioneer: The foreign policy of the South African Police Service. In Sidiropoulos, E, (Ed), South Africa's foreign policy 1994-2004: Apartheid past, Renaissance future (pp.169-182). Johannesburg: The South African Institute of International Affairs.

Zeleza, P. T., (2009). "What Happened to the African Renaissance? The Challenges of Development in the Twenty-First Century, Project, MUSE, Today's Research. Tomorrow's Inspiration, Comparative Studies of South Asia, Africa and the Middle East, 2, 29 (2), 155-170. 